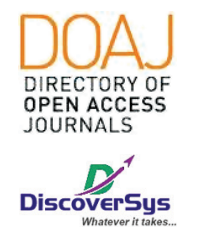

Published by DiscoverSys

\section{Hubungan lingkar perut dengan kadar gula darah puasa pada mahasiswa Fakultas Kedokteran Universitas Udayana angkatan 2014}

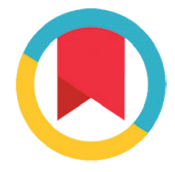

CrossMark

\author{
Alvin Wijaya, ${ }^{* *}$ Nyoman Wande, ${ }^{2}$ Ida Ayu Putri Wirawati ${ }^{2}$
}

\section{ABSTRACT}

Introduction: Diabetes Mellitus is a metabolic disease characterized by elevated blood sugar levels, either caused by a disturbance of insulin secretion, insulin resistance or both. Obesity is one of the risk factors of diabetes mellitus. The incidence of diabetes mellitus increases from year to year, but the data that discusses the association of risk factors with diabetes mellitus itself, especially obesity is minimum. The purpose of this study is to determine the association of abdominal circumference with fasting blood sugar levels at students of Udayana University Faculty of Medicine class of 2014.

Method: This research is an analytical research conducted at Udayana University Faculty of Medicine Campus, Denpasar. Data obtained in the form of primary data in the form of abdominal circumference to see the status of obesity and fasting blood sugar to see the status of diabetes mellitus. Data were analyzed using SPSS program. Result: The results showed that there was not significant negative association between abdominal circumference with fasting blood sugar levels at Udayana University, Faculty of Medicine students class of 2014. However, this association is not statistically significant because diabetes mellitus influenced by many factors other than obesity. In addition, it can be seen that the characteristics of the population did not describe the population of diabetes mellitus or obesity, thus affecting associations that have been described in some literature and the concept of author thinking. But indeed the association of anthropometric risk factors (abdominal circumference) has a greater value than other risk factors. Conclusion: There was a negative correlation between abdominal circumference and fasting blood sugar but not significant statistically
'Program Studi Pendidikan Dokter, Fakultas Kedokteran Universitas Udayana

${ }^{2}$ Bagian/SMF Patologi Klinik, Fakultas Kedokteran, Universitas Udayana-RSUP Sanglah

*Correspondence to: Alvin Wijaya, Program Studi Pendidikan Dokter, Fakultas Kedokteran Universitas Udayana alvinwijayaaa96@gmail.com

Diterima: 03-04-2018 Disetujui: 04-05-2018 Diterbitkan: 01-08-2019
Keywords : Diabetes Mellitus, Obesity, Abdominal Circumference, Fasting Blood Sugar Cite This Article: Wijaya, A., Wande, N., Wirawati, I.A.P. 2019. Hubungan lingkar perut dengan kadar gula darah puasa pada mahasiswa Fakultas Kedokteran Universitas Udayana angkatan 2014. Intisari Sains Medis 10(2): 279-283. D0I: 10.15562/ism.v10i2.191

\section{ABSTRAK}

Latar Belakang: Diabetes Mellitus merupakan penyakit metabolik yang ditandai dengan naiknya kadar gula darah, baik disebabkan oleh gangguan pada sekresi insulin, resistensi terhadap insulin maupun karena keduanya. Obesitas merupakan salah satu dari faktor risiko terjadinya diabetes mellitus. Angka kejadian diabetes mellitus meningkat dari tahun ke tahun, namun data yang membahas mengenai hubungan faktor risiko dengan diabetes mellitus sendiri terutama obesitas sangat sedikit. Tujuan penelitian ini yaitu untuk mengetahui hubungan lingkar perut dengan kadar gula darah puasa pada mahasiswa Fakultas Kedokteran Universitas Udayana angkatan 2014.

Metode: Penelitian ini merupakan penelitian analitik yang dilakukan di Kampus Fakultas Kedokteran Universitas Udayana, Denpasar. Data yang diperoleh berupa data primer berupa lingkar perut untuk melihat status obesitas dan kadar gula darah puasa untuk melihat status diabetes mellitus. Data dianalisis dengan menggunakan program SPSS.

Hasil: Penelitian menunjukkan bahwa terdapat hubungan negatif tidak bermakna antara lingkar perut dengan kadar gula darah puasa pada mahasiswa Fakultas Kedokteran Universitas Udayana angkatan 2014. Namun hubungan ini tidak bermakna secara statistik dikarenakan diabetes Mellitus dipengaruhi banyak faktor lain selain obesitas. Selain itu dapat dilihat bahwa karakteristik populasi pun tidak menggambarkan populasi diabetes mellitus maupun obesitas sehingga mempengaruhi hubungan yang sudah dijabarkan dalam beberapa literatur serta konsep berpikir penulis. Namun memang hubungan faktor risiko antropometri (lingkar perut) memiliki nilai yang lebih besar dibandingkan faktor risiko yang lainnya.

Simpulan: Terdapat korelasi negatif antara lingkar perut dengan kadar gula darah puasa, namun tidak bermakna secara statistik
Kata Kunci : Diabetes Mellitus, Obesitas, Lingkar Perut, Gula Darah Puasa.

Cite Pasal Ini: Wijaya, A., Wande, N., Wirawati, I.A.P. 2019. Hubungan lingkar perut dengan kadar gula darah puasa pada mahasiswa Fakultas Kedokteran Universitas Udayana angkatan 2014. Intisari Sains Medis 10(2): 279-283. D0I: 10.15562/ism.v10i2.191 


\section{PENDAHULUAN}

Diabetes Mellitus adalah penyakit metabolik yang ditandai dengan naiknya kadar gula darah, baik disebabkan oleh gangguan pada sekresi insulin, resistensi terhadap insulin maupun karena keduanya. Gejala dari Diabetes Mellitus sendiri biasanya adalah sering buang air kecil (poliuri), sering haus (polidipsi), cepat merasa lapar (poliphagi), mudah kelelahan dan merasa lemah, penurunan berat badan yang cepat, penglihatan kabur, dan luka yang sulit sembuh. Diabetes Mellitus adalah penyakit kronik yang tidak dapat disembuhkan tetapi kadar gula darah penderita bisa dikendalikan melalui pola hidup dan obat-obatan. ${ }^{1}$

Tingginya kadar gula darah seringkali dikaitkan dengan obesitas, terutama obesitas sentral yang secara bermakna berhubungan dengan sindrom metabolik (dislipidemia, hiperglikemia, hipertensi). Beberapa penelitian bahkan menyebutkan bahwa penurunan berat badan secara signifikan mengurangi faktor resiko Diabetes Mellitus yang berhubungan dengan komplikasi. Obesitas sentral sendiri dapat dikatakan sebagai akumulasi lemak secara intraabdominal dan subkutan di daerah abdomen sehingga pengukuran lingkar perut dapat digunakan untuk mengukur lemak visceral dan digunakan untuk menentukan cut-off dari obesitas sentral. ${ }^{2,10} \mathrm{Hal}$ ini yang mendasari ide yang mengaitkan obesitas dengan kenaikan kadar glukosa darah yang pada konteks ini adalah lingkar perut dengan kadar gula darah puasa.

Pola hidup masyarakat khususnya remaja saat ini sering kali memiliki aktivitas fisik dan tidur yang kurang. Hal ini dapat meningkatkan terjadinya perubahan dalam metabolisme tubuh seseorang. Perubahan metabolisme in yang akan berdampak pada obesitas maupun Diabetes Mellitus itu sendiri. ${ }^{2}$ Hal ini yang kemudian menyebabkan diperlukannya pembelajaran lebih lanjut mengenai gambaran tersebut dan apakah memang terdapat korelasi yang signifikan antara kedua variabel.

\section{METODE}

Penelitian ini merupakan penelitian analitik dimana pengukuran diukur secara simultan, satu kali saja dalam satu waktu, tanpa diikuti dengan follow up. Rancangan penelitian ini bertujuan untuk dapat menggambarkan hubungan obesitas dengan Diabetes Mellitus yang pada hal ini adalah lingkar perut dengan kadar gula darah puasa. Penelitian ini dilakukan di Kampus Fakultas Kedokteran Universitas Udayana, Jalan P.B. Sudirman, Dangin Puri Klod, Denpasar Barat, Kota Denpasar, Bali. Penelitian dilakukan selama satu bulan yaitu pada bulan November 2017.
Adapun populasi dari penelitian ini adalah mahasiswa Program Studi Pendidikan Dokter Fakultas Kedokteran Universitas Udayana angkatan 2014. Sampel pada penelitian ini ini adalah Mahasiswa yang tidak sedang mengalami beberapa penyakit yang dapat mengganggu hasil pemeriksaan gula darah seperti kelainan pada fungsi pankreas, hati, ginjal, ataupun kelenjar adrenal. Penelitian ini dilakukan terhadap 34 sampel yang dipilih secara acak menggunakan random sampling.

Variabel penelitian ini dikelompokkan menjadi variabel bebas, variabel perancu, dan variabel terikat. Variabel bebas dari penelitian ini adalah besar lingkar perut subjek. Variabel terikat pada penelitian ini adalah peningkatan kadar gula darah puasa subjek. Variabel perancu pada penelitian ini bisa merupakan waktu puasa subjek, kelainan metabolisme subjek yang menyebabkan terganggunya kadar gula darah, dan kelainan metabolisme yang menyebabkan dislipidemia.

Analisis data menggunakan aplikasi SPSS yang dibagi menjadi analisis univariat, uji normalitas, serta uji korelasi. Analisis Univariat digunakan untuk melihat gambaran umum sampel sedangkan analisis bivariat yang digunakan adalah uji normalitas (Kolomogorov-Smirnov dan Shapiro-wilk) serta uji korelasi (Pearson dan Spearman).

Pada penelitian ini subjek diberikan penjelasan lengkap mengenai latar belakang, tujuan, dan manfaat dari penelitian ini, kemudian dimintai persetujuan dengan menandatangani Informed Consent.

Pengukuran lingkar perut dilakukan menggunakan pita ukur yang dilakukan saat subjek melakukan ekspirasi maksimal. Diusahakan pita ukur langsung bersentuhan dengan kulit subjek, namun jika subjek menolak, penelitian dapat dilakukan dengan kondisi subjek mengenakan pakaian yang cukup tipis untuk memperkecil terjadinya kesalahan pengukuran. Pengukuran dilakukan mengikuti prosedur yang diinstruksikan oleh WHO pada titik tengah antara margin bawah rusuk terakhir dan

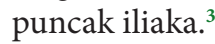

Pengukuran gula darah dilakukan dengan menggunakan alat glucometer easy touch dan dilakukan setelah subjek puasa selama minimal 8 jam. ${ }^{4}$ Puasa yang dimaksud adalah tidak ada kalori yang masuk selama rentang waktu tersebut. Pengukuran dilakukan dengan mengambil sampel darah perifer pada jari pasien, yang dilakukan dengan menggunakan alat penusuk.

\section{HASIL PENELITIAN}

\section{a. Gambaran Umum Penelitian}

Dari 34 sampel yang diteliti dalam penelitian ini, didapatkan hasil sebagian besar memiliki lingkar perut di bawah cut-off untuk obesitas sentral 
Tabel 1 Lingkar perut dan gula darah puasa

\begin{tabular}{llcc}
\hline Subjek & & F & $\%$ \\
\hline Lingkar Perut & Di atas cut-off & 5 & $14 ., 1$ \\
& Di bawah cut-off & 29 & 85,29 \\
Gula & Diabetes & 0 & 0.00 \\
Darah Puasa & Prediabetes & 4 & 11,76 \\
& Normal & 30 & 88,24 \\
\hline
\end{tabular}

Tabel 2 Uji Normalitas Kolmogorov-Smirnov

\begin{tabular}{lccc}
\hline & Statistik & df & Sig. \\
\hline Gula darah & 0,102 & 33 & 0,200 \\
Lingkar perut & 0,119 & 33 & 0,200 \\
\hline
\end{tabular}

Tabel 3 Uji Korelasi Pearson

\begin{tabular}{llcc}
\hline & & Lingkar perut & Gula darah \\
\hline Lingkar perut & Pearson Correlation & 1 & $-0,199$ \\
& Nilai p & & 0,267 \\
& $\mathrm{~N}$ & 34 & 34 \\
Gula darah & Pearson Correlation & $-0,199$ & 1 \\
& Nilai p & 0,267 & 34 \\
\hline
\end{tabular}

(85.29\%) dan hanya sedikit yang memiliki lingkar perut di atas cut-off untuk obesitas sentral (14.71\%).

Dapat dilihat pula bahwa tidak ada kadar gula darah puasa dalam rentang diagnosa diabetes $(0.00 \%)$, hanya sebagian kecil yang berada dalam rentang prediabetes $(11.76 \%)$, dan sebagian besar berada dalam batas normal (88.24\%).

\section{b. Uji Normalitas}

Berdasarkan tabel 2 dapat diketahui bahwa menurut uji Kolmogorov-Smirnov didapatkan hasil bahwa data normal (nilai $\mathrm{p}>0,05$ ).

\section{c. Uji Korelasi}

Uji korelasi antara lingkar perut dengan kadar gula darah menggunakan uji korelasi Pearson karena menurut uji distribusi didapatkan hasil normal dimana hasilnya menunjukkan bahwa kedua variabel memiliki hubungan negatif namun tidak memiliki kesamaan makna atau tidak signifikan.

\section{DISKUSI}

Berdasarkan hasil penelitian pada mahasiswa Fakultas Kedokteran Universitas Udayana angka$\tan 2014$, hubungan positif antara lingkar perut dengan kadar gula darah puasa tidak terbukti. Uji korelasi antara lingkar perut dengan kadar gula darah puasa dilakukan menggunakan uji pearson karena salah satu variabel yaitu lingkar perut tidak terdistribusi normal sedangkan variabel yang lain yaitu gula darah puasa berdistribusi normal. Sebaliknya, terdapat hubungan negatif pada penelitian ini sehingga memiliki interpretasi semakin tinggi lingkar perut sampel, semakin rendah kadar gula darahnya namun hal ini juga tidak signifikan secara statistik. Hal ini tidak sesuai dengan penelitian sebelumnya dan konsep pemikiran peneliti untuk menghubungkan lingkar perut yang menggambarkan obesitas dengan kadar gula darah puasa yang menggambarkan status diabetes.

Penelitian ini memiliki hasil yang berlawanan dengan penelitian sebelumnya yang dilakukan oleh Novena di Yogyakarta yang menyatakan bahwa terdapat korelasi positif dengan kekuatan lemah $(r=0,244)$ tidak bermakna $(\mathrm{p}=0,102)$ antara lingkar perut terhadap kadar HbA1c. ${ }^{5}$ Novena menggunakan HbAlc untuk melihat gambaran diabetes sedangkan peneliti menggunakan gula darah puasa. Berdasarkan konsensus Perkeni kedua kriteria tersebut dapat digunakan untuk menilai status diabetes seseorang. ${ }^{4}$ Namun memang kadar HbAlc digunakan sebagai gold-standard dalam diagnosa diabetes. Pada sampel yang dilakukan oleh peneliti dengan peningkatan gula darah puasa mungkin saja mengalami Glukosa Darah Puasa Terganggu (GDPT) yaitu Hasil pemeriksaan glukosa plasma puasa antara $100-125 \mathrm{mg} / \mathrm{dl}$ dan pemeriksaan TTGO glukosa plasma 2-jam $<140 \mathrm{mg} / \mathrm{dl} .{ }^{4}$ Pemeriksaan TTGO tidak dilakukan pada penelitian ini. Namun untuk faktor risiko terjadinya anomali ini tidak dapat ditentukan. Peningkatan gula darah kronik dan akut juga bisa dikaitkan dengan data yang ada karena penelitian dengan menggunakan HbAlc, kadar HbAlc jauh dibawah ambang batas kategori diabetes $(\geq 6,5 \%)$ sebab HbA1c merupakan indikator yang lebih baik untuk peningkatan gula darah kronik dan komplikasi jangka panjang. ${ }^{4}$

Penelitian lainnya yang dilakukan oleh Indrawaty dan Erizel untuk populasi di Padang menunjukkan hasil tidak terdapat hubungan antara lingkar perut maupun variabel antropometri yang lainnya dengan gula darah puasa. ${ }^{6}$ Dalam penelitian tersebut dijelaskan bahwa pola hidup dan pola konsumsi masyarakat yang masih tradisional melindungi masyarakat dari risiko penyakit degeneratif dan metabolik. Meski demikian, dalam penelitiannya disebutkan juga bahwa lingkar perut $(r=0,186)$ memiliki hubungan yang lebih besar dengan gula darah puasa dibandingkan variabel antropometri yang lain seperti IMT dan lingkar panggul. ${ }^{6}$ Hal ini sesuai dengan penelitian World Health Organization (WHO) yang menyatakan bahwa obesitas sentral lebih berkorelasi dengan berbagai penyakit termasuk diabetes. Penelitian 
yang dilakukan peneliti, Novena, serta Indrawaty dan Erizel memiliki hasil yang berbeda-beda. karakteristik populasi pun berbeda sehingga faktor risiko lain yang tidak disebutkan dalam literatur seperti lokasi, kondisi geografis, pola hidup, pola konsumsi, dan lain-lain perlu dipertimbangkan untuk menentukan hubungan yang lebih lanjut antara obesitas dengan diabetes. Jenis kelamin juga menjadi pertimbangan dalam penelitian tersebut dengan hasil peningkatan nilai antropometri pada wanita lebih berpengaruh terhadap kadar glukosa darah dibandingkan pria walaupun nilai korelasinya sangat rendah dan tidak bermakna.

Beberapa faktor yang dapat menyebabkan terjadinya hasil dalam penelitiaan ini antara lain adalah karakteristik populasi dan prosedur penelitian. Obesitas sendiri merupakan satu dari sekian faktor risiko terjadinya diabetes. ${ }^{2}$ Dalam penelitian ini tidak dilakukan pengujian terhadap variabel faktor risiko yang lain seperti ras, umur, IMT (indeks massa tubuh), tekanan darah, kadar kolesterol, dan riwayat diabetes pada keluarga. Banyaknya hal lain yang bisa menyebabkan risiko terjadinya diabetes pun menjadi salah satu penyebab tidak terbuktinya hipotesa peneliti pada penelitian ini. Populasi yang diperiksa pada penelitian ini merupakan mahasiswa Fakultas Kedokteran Universitas Udayana angkatan 2014. Populasi ini merupakan populasi dari rentangan umur remaja dan kebanyakan masih aktif sehingga bukan merupakan gambaran umum dari masyarakat dengan diabetes, namun lebih cenderung merupakan populasi masyarakat yang masih sehat dan produktif. Riwayat diabetes dalam keluarga sampel juga tidak dianalisis padahal untuk kasus diabetes mellitus tipe 1, faktor genetik lebih berpengaruh terhadap kenaikan gula darah dibandingkan dengan faktor antropometri dan pola hidup.

Untuk pengukuran kadar gula darah puasa menggunakan glucometer easytouch. Pada penelitian ini dilakukan pengecekan gula darah sebanyak 2 kali kemudian diambil rata-ratanya. Pengecekan yang semakin banyak akan memberikan rata-rata yang lebih akurat. Namun pengecekan dengan mengambil darah perifer disebutkan memiliki rentang yang lebih rendah daripada pengambilan darah plasma vena. ${ }^{4}$ Hal ini dapat menyebabkan penurunan rentangan untuk status diabetes hingga $20 \mathrm{mg} / \mathrm{dL}$ (bukan diabetes menjadi kurang dari 90, prediabetes menjadi di antara 90 sampai 99 , dan diabetes menjadi di atas 100). ${ }^{4}$ Pada penelitian yang dilakukan Tonyushkina dijabarkan bahwa pengukuran gula darah dengan glucometer memiliki kriteria analitik yang dapat ditoleransi sebesar $\pm 20 \mathrm{mg} / \mathrm{dL}$ untuk kadar gula darah di bawah $100 \mathrm{mg} / \mathrm{dL} .{ }^{8}$ Sehingga jika diberikan sebuah contoh didapatkan hasil sebesar $50 \mathrm{mg} / \mathrm{dL}$, maka hasil tersebut memiliki rentangan dengan batas paling rendah $30 \mathrm{mg} / \mathrm{dL}$ dan batas atas $70 \mathrm{mg} / \mathrm{dL}$. Untuk batas bawah dan batas atas tersebut memiliki perbedaan interpretasi yang sangat signifikan (severe hipoglycemic dan normal). Tentu hal ini sangat sulit untuk menegakkan diagnosis sehingga sangat diperlukan gambaran klinis sampel yang diperiksa juga pemeriksaan lainnya yang lebih akurat seperti pemeriksaan plasma vena. ${ }^{4}$ Penelitian menggunakan plasma vena dilihat lebih sesuai untuk diagnosa diabetes menggunakan rentangan perkeni. ${ }^{4}$ Ketaatan sampel dalam menjalankan puasa juga bisa menjadi salah satu faktor kelemahan dalam penelitiaan ini karena peneliti hanya dapat memantau sebatas pemberian edukasi dan briefing sebelum melakukan penelitian. Puasa yang dianjurkan adalah tidak ada asupan kalori selama 8 jam. ${ }^{4}$

Pada penelitian ini, lingkar perut belum dapat digunakan sebagai prediktor diabetes karena memiliki nilai korelasi yang lemah dan tidak signifikan, sehingga perlu digali faktor-faktor lain yang menyebabkan terjadinya hal seperti yang disebutkan dalam pembahasan ini. Untuk hubungan antara lingkar perut dengan kadar gula darah puasa nya sendiri menjadi tidak berhubungan oleh karena banyak faktor yang bisa mempengaruhi hasil. Selain itu jumlah sampel yang sedikit juga mungkin tidak representatif untuk mewakili populasi. Penambahan jumlah sampel diperlukan untuk mendapat hasil yang lebih optimal dan distribusi sampel menjadi lebih normal. Penelitian ini juga hanya menggunakan pengukuran yang bersifat kuantitatif. Banyak faktor kualitatif lainnya yang perlu dilakukan sehingga akan lebih baik jika menggabungkan faktor kuantitatif dan kualitatif. Faktor kualitatif yang dimaksud adalah tingkat stres atau psikologis, efikasi diri, dukungan sosial, dan manajemen diri sampel. ${ }^{9}$ Dengan pengukuran faktor-faktor yang bersifat kualiatif diharapkan dapat melihat gambaran dan penyebab kenaikan gula darah selain yang disebabkan oleh nilai antropometri. ${ }^{9}$ Peneliti berharap dengan adanya penelitian ini dapat mengetahui dan menghilangkan keluhan DM, memperbaiki kualitas hidup, dan mengurangi risiko komplikasi akut. selain itu juga diharapkan dapat dilakukan penelitian lainnya untuk membantu menurunkan morbiditas dan mortalitas DM.

\section{SIMPULAN}

Terdapat hubungan negatif tidak bermakna antara lingkar perut dengan kadar gula darah puasa pada mahasiswa Fakultas Kedokteran Universitas Udayana angkatan 2014. Selain itu dapat disimpulkan pula bahwa populasi mahasiswa Fakultas Kedokteran Universitas Udayana angkatan 2014 
bukan merupakan populasi yang menggambarkan keadaan obesitas maupun diabetes mellitus.

\section{DAFTAR PUSTAKA}

1. American Diabetes Association. Standards of medical care in diabetes-2012. Diabetes Care.2012;35 (suppl 1) : S11-S63

2. Perkumpulan Endokrinologi Indonesia. Panduan Pengelolaan Dislipidemia di Indonesia, PB. PERKENI. Jakarta. 2015

3. Waist circumference and waist-hip ratio: report of a WHO expert consultation, Geneva, 8-11 December 2008.

4. Perkumpulan Endokrinologi Indonesia. Konsensus Pengelolaan dan Pencegahan Diabetes Mellitus Tipe 2 di Indonesia, PB. PERKENI. Jakarta. 2015

5. Yuhara, NA, 2016. Korelasi Lingkar Pinggang Dan Rasio Lingkar Pinggang Panggul Terhadap HbAlc Pada Pria Dewasa Sehat Di Desa Kepuharjo Kecamatan Cangkringan Sleman Yogyakarta. Yogyakarta
6. Lipoeto NI, Yerizel E, Edward Z, Widuri, I., 2007. Hubungan Nilai Antropometri dengan Kadar Glukosa Darah. Padang

7. Perkumpulan Endokrinologi Indonesia. Petunjuk Praktis: Terapi Insulin Pada Pasien Diabetes Melitus, PB. PERKENI. Jakarta. 2015

8. Tonyushkina K, Nichols JHJ. Glucose meters: a review of technical challenges to obtain accurate results. J Diabetes Sci. Technol. 2009;3:971-980.

9. Hasanat, N.U., 2015. Manajemen Diri Diabetes Analisis Kuantitatif Faktor- Faktor Psikososial Pada Pasien Diabetes Melitus Tipe II. Yogyakarta.

10. Mansouri A, Vahed AS, Shahdadi H, Dashtban F, Arbabisarjou A. The effect of garlic and cumin on blood pressure and glycosylated hemoglobin in patients with type 2 diabetes. Bali Med J. 2018;7(1):156-160.

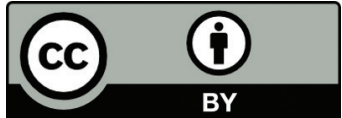

This work is licensed under a Creative Commons Attribution 